\title{
Forecast of Changes in Business Administration Driven by Digitalization
}

\author{
Susann Wieczorek¹, Sven Ludwig1, Lars Büttner², Mathias R. Bauer³, Peter Markovič4 \\ ${ }^{1}$ West Saxon University of Applied Sciences of Zwickau, Zwickau, Germany \\ ${ }^{2}$ City University of Applied Sciences Bremen, Bremen, Germany \\ ${ }^{3}$ University of Applied Sciences Augsburg, Augsburg, Germany \\ ${ }^{4}$ Department of Corporate Finance Bratislava, University of Economics in Bratislava, Bratislava, Slovakia \\ Email: susann.wieczorek@fh-zwickau.de, sven.ludwig@fh-zwickau.de, lars.buettner@hs-bremen.de, mathias.bauer@thi.de, \\ peter.markovic@euba.sk
}

How to cite this paper: Wieczorek, S., Ludwig, S., Büttner, L., Bauer, M. R., \& Markovič, P. (2021). Forecast of Changes in Business Administration Driven by Digitalization. Open Journal of Business and Management, 9, 1680-1695.

https://doi.org/10.4236/ojbm.2021.94092

Received: April 28, 2021

Accepted: July 10, 2021

Published: July 13, 2021

Copyright $\odot 2021$ by author(s) and Scientific Research Publishing Inc. This work is licensed under the Creative Commons Attribution International License (CC BY 4.0).

http://creativecommons.org/licenses/by/4.0/

\begin{abstract}
This paper on hand deals with a research gap, since there were no sources on the topic of changes in business administration studies induced by Industry 4.0 until the year 2018. For this reason, a document analysis was used to examine essential studies from the years 2010 to 2016. This was followed by twenty interviews with experts from universities and companies. Furthermore, a total of 71 people took part in a subsequent online survey. With digitization, the requirements for business administration graduates are also changing from technical competence to methodological and digital competence. Digitization has an impact on all areas, politics, society and the economy. The higher education sector is not unaffected by this either, because universities are forerunners in the transfer of knowledge. For this reason, there is a need to reform and at the same time strengthen the education system. Educational institutions should focus on effective learning and relevant learning content. Thus, the present research deals with the changes at university (especially business studies) and company level induced by Industry 4.0, focusing on the demands on business economists coupled with the entrepreneurial changes of tomorrow. Using the mixed-method approach, a qualitative and a quantitative research approach was carried out. This was based on a three-step sequential research approach: 1) document analysis, 2) expert interviews and 3) online surveys. As a result, the majority of the experts that have participated in the survey confirmed a strong impact of digitalization on the working environment. This change of the workplace requires an adaption by the employees as well as a revision of academic curriculars. Traditional education in business administration is not obsolete, however, requires a stronger link with topics of information technologies. Business administration in higher
\end{abstract}


education must be subject to the following changes: 1) adaptation of curricula with regard to current trends business analytics, blockchain, artificial intelligence, 2) adaptation of IT infrastructure and resources in knowledge transfer such as blogs, online lectures, etc. as well as 3) stronger cooperation between business, science and education.

\section{Keywords}

Forecasting, Digitalization, Industry 4.0, Business Process Management, Higher Education, Digital Innovation, Business Administration

\section{Introduction}

Universities are more and more critized because they train graduates who are needed less and less. Companies at all stages of the survey repeatedly pointed out that universities will have to change in response to the changes brought about by Industry 4.0. From the company's point of view, it is necessary that the practical component of business studies be increased. Society is calling for change.

At the World Economic Forum 2020 (WEF, 2020), moreover, the term technology was one of the key topics that have been discussed. More than $50 \%$ of the world's population has access to the World Wide Web and about $2 / 3$ of the people own a mobile device. In today's world, companies are faced with the major challenge of implementing Industry 4.0 and the associated technological infrastructures as well as adapting business processes. The changing market requirements, due to the fast-growing challenges induced by technologization and automation, promote competition between companies (Casper-Hehne \& Reiffenrath, 2017).

Companies interact in increasingly complex systems and are therefore usually dependent on an intact system landscape of suppliers and customers (Wieczorek \& Dorčak, 2020). At this point, the cooperation between public institutions and companies should also be mentioned. Universities, which serve as trailblazers in the transfer of knowledge, are also trying to implement this technological change (World Economic Forum, 2020). The high market dynamics and flexibility require companies, universities and managers to recognize opportunities and find adequate solutions (Kirsch \& Picot, 2013).

In addition to the WEF 2020, other authors (Ahmad \& Van Looy, 2020) and (Androniceanu, Georgescu, Tvaronavičiene, \& Androniceanu, 2020) have dealt with the topic of digitalization and its changes in the corporate and academic world. This paper shows the changes induced by Industry 4.0 on business studies and their effects on the business world. In order to address the link between digitalization, companies \& universities as well as job requirements and academic education, the authors have started an (pre-pandemic) empirical research by 2018/ 2019. We already know that some jobs will have to change. The influence of IT 
solutions and diverse technologies is becoming ever stronger. This scientific paper shows which areas of business administration are particularly affected and how exactly this change is taking place. Questions are clarified that deal with the effects on curricula, on the IT infrastructure of universities and on the cooperation with business and science.

In the context of this study, two research questions were investigated:

1) What changes are occurring in business administration studies as a result of Industry 4.0? The answer to this question leads to the second research question: which demands are made on business administration graduates in the digitalized age. In essence, the question aims to find out what influence Industry 4.0 has on business studies, in particular on professional, methodological, social and digital skills.

2) What competencies are important for tomorrow's business administration graduates (from the perspective of companies and universities)? This paper outlines the major changes in business administration studies which are due to shifts in competencies. Current trends and changing teaching content will be elaborated for academia, teaching and practice.

The article is organized in six chapters. At the beginning, the focus is on the scientific examination of the topic of Industry 4.0 and its effects on the university landscape. The third chapter deals with the methodological research project, in which the research design and project are described in more detail, thus the mixed-method design is described in more detail. This chapter is based on the empirical data and analysis using SPSS, in which the hypotheses are compared and the Cronbach's alpha provides information about their interpretability and reliability. The two different quantitative studies (companies vs. universities) are placed side by side in the fifth chapter and the hypotheses are verified or falsified. Subsequently, the results of the work are interpreted and their effect on the study of business administration is examined in more detail. The last chapter summarizes the findings and rounds off this scientific work with an outlook.

\section{Literature and Theory Section}

Due to the low number of scientific sources dealing with Industry 4.0 in business administration studies in 2017-18, this research project is based on a mixed-methods design. Nevertheless, research results will be consulted that deal with this topic rudimentarily.

Since the implementation of the Bologna process, universities secure the employability of students (Kröber, 2017). The employability and labor market capability indicates whether a person can find a first job, maintain himself in it and develop it further. This definition can be extended by individual knowledge, skills and abilities as well as personality (Bauer \& Sadei, 2015). Thus, the employment success of graduates can be seen as an indicator of performance in studies and teaching. It is a matching-index between graduates and labor market demand and a key qualification in study orientation (Hessler, 2013). 
The engine of most economies are, in particular, small and medium sized enterprises (SMEs). In contrast to global players, SMEs have the ability to adapt more quickly to changing market conditions. With the age of digitalization, these players are facing ever greater challenges. (Hirsch-Kreinsen, 2017) makes it clear that those who do not want to keep pace with this development in the context of Industry 4.0 will probably have difficulties in the long term. In order to create the preconditions for Industry 4.0, companies must work out their core components from the perspective of the value chain (Hirsch-Kreinsen, 2017).

Innovative ideas resulting from higher education can overcome such obstacles. Education, thus, becomes a crucial driver of innovation. Governments are funding (start-up-) companies with subsidies. While, on the contrary, science and education are continuously supported in terms of equipment, teaching materials and resources. The economy finances this education and, in turn, benefits from a new workforce. Thus, there is a triangular relationship between the state, the economy, and science/education.

Digitization is making inroads in Germany, as it is in other nations. In this way, politics has also noticed the changes for itself and is increasingly reacting. In 2019, the German parliament has passed administrative agreement called "DigitalPakt Schule" in the amount of $€ 5 \mathrm{bn}$. In it, the German government pledges financial support for the states and municipalities in equipping schools with IT (e.g., modern teaching and learning techniques, including presentation techniques, WLAN in classrooms, working with mobile devices, data protection aspects) (Bundesministerium für Bildung und Forschung, 2020). Pupils would already be familiarized with digitization at an early age. As a result, they would be better prepared for planned business studies and professional life.

\section{Materials and Methods}

The literature review was the starting point for the research design, which consists of three sequential research phases: 1) document analysis, 2) expert interviews and 3) online surveys. This cross-sectional scientific investigation is based on a three-step mixed-method approach.

The individual competencies of the graduates were transferred to the business studies program with the aim of finding out what demands will be placed on tomorrow's graduates. After a comparison of the studies, the coding into a selfdefined category system followed. From the: (1) analyzed documents, content was identified that was considered important for the business studies program. MAXQDA, a program for qualitative data and text analysis, was used for this purpose. Meaningful text contributions were categorized and provided with codes. The individual codes were evaluated according to relevance or importance. In the same way, the competencies have been weighted.

The (2) interviews were recorded with a dictation machine. With the written notes and the recording of the dictation machine, the interviews could be transcribed and evaluated again with the help of MAXQDA. Relevant text passages 
were also provided with codes. The transcribed protocols were evaluated using two methods: qualitative content analysis according to Philipp Mayring and grounded Theory in accordance with Anselm Strauss.

In the course of 20 interviews from the corporate and university environment in mid/late 2018 and the document analysis, essential insights for the two sequential online surveys were gained. Table 1 shows the attributes of those participants:

Due to the different survey groups, the (3) quantitative online inquiry was divided into two surveys, the company and the university survey. In order to test the functionality of the online survey, it was provided to a test person in advance (pretest). As a result of the pretest, the online survey could be answered within ten minutes. As the survey did not change significantly for the universities, except for sociodemographic data, no further pretest was conducted. Before the company surveys, hypotheses were formed based on the expert interviews. The objectives of this study were: 1) to determine the satisfaction of the companies with regard to Industry 4.0 in business studies and 2) to identify current and upcoming trends in companies and to derive essential content for business studies.

Table 1. Sociodemographic skills from the interview experts.

\begin{tabular}{|c|c|c|c|c|c|}
\hline No. & Gender & Age & Institution & Position & Experience \\
\hline 1 & Female & $41-50$ & Company & CEO & 7 - 10 years \\
\hline 2 & Male & $41-50$ & University & Head of study & $7-10$ years \\
\hline 3 & Male & $51-60$ & Company & CEO & $>10$ years \\
\hline 4 & Male & $51-60$ & University & Head of study & $7-10$ years \\
\hline 5 & Male & $41-50$ & Company & CEO & 4 - 6 years \\
\hline 6 & Female & $41-50$ & University & Head of study & 7 - 10 years \\
\hline 7 & Male & $41-50$ & University & Head of study & $7-10$ years \\
\hline 8 & Male & $31-40$ & Company & HR-Manager & 4 - 6 years \\
\hline 9 & Female & $41-50$ & University & Head of study & $7-10$ years \\
\hline 10 & Female & $>60$ & Company & HR-Manager & $0-3$ years \\
\hline 11 & Male & $41-50$ & Company & $\mathrm{CDO}$ & 7 - 10 years \\
\hline 12 & Male & $31-40$ & Company & $\mathrm{CEO}$ & $4-6$ years \\
\hline 13 & Male & $51-60$ & University & Head of study & 7 - 10 years \\
\hline 14 & Female & $41-50$ & Company & HR-Manager & 4 - 6 years \\
\hline 15 & Male & $41-50$ & University & Head of study & $0-3$ years \\
\hline 16 & Female & $31-40$ & Company & HR-Manager & $0-3$ years \\
\hline 17 & Male & $41-50$ & Company & HR-Manager & $>10$ years \\
\hline 18 & Male & $41-50$ & Company & $\mathrm{CDO}$ & $>10$ years \\
\hline 19 & Male & $>60$ & University & Head of study & 7 - 10 years \\
\hline 20 & Female & $31-40$ & University & Head of study & 4 - 6 years \\
\hline
\end{tabular}


41 persons participated in the survey. The survey consisted of 25 questions. Inferential statistics and descriptive statistics (mean values, standard deviations) were used. In most cases, closed questions were asked. The educational institutions were surveyed after the companies, in total 30 persons. Thirty people participated in the survey, including course directors and assistants, academic staff and deans of higher education institutions. A detailed examination of the online survey, similar to Table 1, will be omitted here due to the 71 participants. The last chapter summarizes the findings and rounds off this scientific work with an outlook.

\section{Empirical Data and Analysis}

Representatives from companies and universities were contacted sequentially with different online questionnaires. The survey with a focus on companies was conducted between December 2018 and February 2019. Hypotheses were formulated for the survey based on the expert interviews that have been conducted in advance. In addition, essential requirements from the digital environment published at the then last WEF 2018 were taken into account. The aim of the online survey conducted for this scientific article was to interview CEOs and HR managers as a target group. On average, the respondents have been in this position for about nine years. Most respondents have worked in small and medium enterprises. It can be stated that the larger the company, the more likely a managing director participated in the survey. The expert interviews showed that Industry 4.0 and digitization bring with them different development cycles and changes in the respective industries.

The online survey comprised 25 individual questions, which were additionally categorized. The resulting data set was read into SPSS with the aim of realizing a descriptive evaluation of defined variables, which can be composed of several items. The abbreviations of the hypothesis "Comp" stand for the answers of the online survey of companies and "Educ" for those of educational institutions.

The first step was to check the information obtained for plausibility and, if necessary, to carry out any adjustments. With the help of Cronbach's alpha see Table 2, optimization possibilities were sought to quantify the consistency of the individual variables and the reliability:

Table 2. Online-survey $1-$ Cronbach's alpha.

\begin{tabular}{lc}
\hline \multicolumn{1}{c}{ Testing variables } & $\begin{array}{c}\text { Cronbach's } \\
\text { alpha }\end{array}$ \\
\hline To what extent do the following competencies matter in terms of bachelor students? & 0.570 \\
To what extent do the following competencies matter in terms of master students? & 0.659 \\
How do you rate the following specialist competencies among master's graduates? & 0.749 \\
How do you rate the following methodological skills among master's graduates? & 0.850 \\
How do you rate the following personal and social skills in master's graduates? & 0.868 \\
\hline
\end{tabular}


After checking the Cronbach's alpha none of these items were eliminated. From the authors' point of view, it made sense to keep all variables. Due to the frequent ordinal scaled variables and the created correlation hypothesis, the Spearman rank correlation analysis was used for evaluation. Spearman examines the linear correlation between at least two variables. To calculate the correlation coefficient $\rho$ (rho) this formula was used.

In this Comp2 hypothesis, the nominal scaled variables of the industry were contrasted with the interval scaled variable degree of digitization, the latter being the dependent variable and the former the independent variable. For this reason, the single factor analysis of variance or single factor ANOVA was used (Ahmad \& Van Looy, 2020). This method checks whether the mean values of the considered groups, which are defined by a categorical independent variable, differ. The factor is described as a categorically independent variable. The following formula was used to calculate the total square sum (SStotal).

In the second online survey, course directors and deans in particular were asked how satisfied they are with their business studies in relation to the digital age and what changes they have already initiated. In total, 30 people took part in this survey. 26 questions were created and took on average ten minutes to answer. Two further hypotheses were formulated for the university side (see Table 4).

For the descriptive analysis of this research phase, Cronbach's alpha was again used and examined in the first step see Table 3; here again, no items were excluded. Eight universities and 22 technical colleges participated in this survey. Most of them teach in bachelor's degree programs in business administration. 16 respondents were often course directors, six assistants, two deans, two persons could be assigned to the academic staff and four stated "other". On average, the respondents have been in this position for eight years. The participating lecturers taught mostly in medium-sized study programs.

In addition to the methods already described, Spearman rank correlation analysis, single factor ANOVO and the binomial test in SPSS were also applied. The binomial test was used to determine whether the number of significant

Table 3. Online-survey 2-Cronbach's alpha.

\begin{tabular}{lc}
\hline \multicolumn{1}{c}{ Testing variables } & $\begin{array}{c}\text { Cronbach's } \\
\text { alpha }\end{array}$ \\
\hline $\begin{array}{l}\text { How do you rate the competencies depending on the importance of a Bachelor } \\
\text { graduate? }\end{array}$ & 0.239 \\
How do you rate the competencies depending on the importance of a master's degree? & 0.540 \\
How do you rate the following specialist competencies among master's graduates? & 0.520 \\
How do you rate the following specialist competencies among master's graduates? & 0.828 \\
How do you rate the following methodological skills among master's graduates? & 0.826 \\
How do you rate the following personal and social skills in master's graduates? & 0.775 \\
\hline
\end{tabular}


results was random. This test is used if one of the variables is dichotomous (Androniceanu, Georgescu, Tvaronavičiene, \& Androniceanu, 2020). For the Educ1 hypothesis, it was examined whether attendance or modular study is more significant for the respondents.

\section{Results}

In this section the results of the two quantitative surveys will be examined and interpreted. Through various preliminary work, including the recoding of variables and the calculation of new variables, statements about the weighting of competencies could be recorded in order to verify or falsify the required hypotheses, including those that could not evaluated (n. e.). All results were evaluated in Table 4 by using IBM SPSS software version 25 (Wieczorek \& Dorčak, 2020).

Table 4. Hypotheses, methodology and results.

\begin{tabular}{|c|c|c|c|c|}
\hline $\begin{array}{l}\text { Hyp. } \\
\text { No. }\end{array}$ & Hypotheses & Statistical & $p$ & Result \\
\hline Comp1 & $\begin{array}{l}\text { The larger an enterprise, the more its digital } \\
\text { competence does matter }\end{array}$ & Methods & 0.000 & verify \\
\hline Comp2 & $\begin{array}{l}\text { The extent of digitalization varies in accordance } \\
\text { with the size of an enterprise }\end{array}$ & $\begin{array}{c}\text { T-Test and } \\
\text { Spearman rank }\end{array}$ & n. e. & falsify \\
\hline Comp3 & $\begin{array}{l}\text { The knowledge base of MBA-students is more } \\
\text { important for their working life than the } \\
\text { professional specialization of the study courses }\end{array}$ & $\begin{array}{l}\text { correlation } \\
\text { analysis }\end{array}$ & 0.217 & falsify \\
\hline Comp4a & $\begin{array}{l}\text { Employers do value students' methodological } \\
\text { competence higher than their expertise }\end{array}$ & $\begin{array}{l}\text { Single factorial } \\
\text { analysis of }\end{array}$ & 0.000 & verify \\
\hline Comp4b & $\begin{array}{l}\text { Employers do value MBA-graduates' } \\
\text { methodological competence higher than their } \\
\text { social competence }\end{array}$ & $\begin{array}{l}\text { variance or } \\
\text { ANOVA }\end{array}$ & 0.000 & verify \\
\hline Comp4c & $\begin{array}{l}\text { For companies, the methodological skills of } \\
\text { business administration graduates are more } \\
\text { important than digital skills }\end{array}$ & $\begin{array}{l}\text { Spearman } \\
\text { rank }\end{array}$ & 0.000 & verify \\
\hline Comp5 & $\begin{array}{l}\text { The higher a company's degree of digitalization, } \\
\text { the more its representatives are likely to engage } \\
\text { in discussions with educational institutions about } \\
\text { digitalization }\end{array}$ & $\begin{array}{l}\text { correlation } \\
\text { analysis }\end{array}$ & 0.009 & verify \\
\hline Comp6 & $\begin{array}{l}\text { Employers value their employers' modular } \\
\text { continuing education (certificate studies, part } \\
\text { time studies) higher than compulsory attendance } \\
\text { studies }\end{array}$ & $\begin{array}{l}\text { Spearman rank } \\
\text { correlation analysis }\end{array}$ & n. e. & verify \\
\hline Educ1 & $\begin{array}{l}\text { Compared with universities, colleges \& } \\
\text { universities of applied sciences prefer modular } \\
\text { courses in terms of corporate continuing } \\
\text { education instead of compulsory attendance } \\
\text { studies }\end{array}$ & $\begin{array}{c}\text { Spearman rank } \\
\text { correlation analysis }\end{array}$ & 0.000 & verify \\
\hline Educ2 & $\begin{array}{l}\text { Universities of applied sciences deal more with } \\
\text { information security than with other modules }\end{array}$ & $\begin{array}{l}\text { Spearman rank } \\
\text { correlation analysis }\end{array}$ & n. e. & falsify \\
\hline
\end{tabular}


Most of the hypotheses were verified. At this point the approach of selected hypotheses and their results will be discussed.

Comp1: The larger a corporation, the more its digital competence matters

This type of hypothesis corresponds to the coherence hypothesis, which requires a null hypothesis: With increasing company size, digital competence does not become more important. In this review, the two ordinally scaled variables company size with the number of employees and the orientation of digital competence with the indication in scale points were compared. To answer this hypothesis, the t-test was used to find out whether these two samples were statistically different. This is to provide a statement as to whether there is a significant correlation between the characteristics. As a result, it can be stated that there is a correlation between increasing company size and the digital competence of business administration graduates. With the help of Spearman's ranking correlation analysis, the significance was tested. With this test it can be concluded that the correlation is statistically significant: $\mathrm{rs}=0.631$ and $p$-value $=0.001$.

Large companies depend on strong digital innovation as well as digital processes to increase their competitiveness and achieve operational efficiency (Androniceanu, Georgescu, Tvaronavičienè, \& Androniceanu, 2020). Digitization forces large companies in particular to have a process-oriented corporate organization, which means that business process management must be developed and expanded.

Clearly structured processes with defined internal and external interfaces are a prerequisite for efficient control and administration (Ahmad \& Van Looy, 2020). A well-developed IT system landscape acts as a key efficiency driver and increases the ability of the entire organization to react quickly to internal and external changes. The dynamics associated with the high level of digitization can generally be seen as a competitive advantage.

Comp2: The extent of digitalization varies in accordance with the size of an enterprise

In this hypothesis the nominal scaled variables of company size were opposed to the degree of digitization, with the latter being the dependent variable and the former the independent variable. Based on the available data, the single factor variance analysis was calculated with the variable degree of digitization. The correlation between company size and digitization level shows a $p$-value of 0.244. Thus Table 5, the hypothesis was falsified.

It is becoming apparent that the size of a company, measured in terms of the number of employees, is not the only factor influencing the level of digitization.

Table 5. Hypothesis Comp2.

\begin{tabular}{cccccc}
\hline Hypothesis & Sum squares & df & Mean of squares & F & $p$ \\
\hline between groups & 8.992 & 11 & 0.817 & 1.388 & 0.244 \\
within groups & 13.546 & 23 & 0.589 & & \\
total & 22.538 & 34 & & & \\
\hline
\end{tabular}


In addition to the competitive advantages already mentioned, the age of the company also plays a leading role. Young companies, which are therefore in an early phase after their founding, also use technologies that support the digitization trend.

Comp3: The knowledge base of MBA-students is more important for their working life than the professional specialization of the study courses

With the hypothesis a differential hypothesis was created. The required null hypothesis is: Basic knowledge and technical specialization are equivalent for professional life. For this purpose, the two variables technical specialization and basic knowledge were chosen. Both variables are scaled in intervals and are shown accordingly via scale points. In order to make a statement for this likewise the rank correlation analysis was selected in accordance with Spearman. The shown correlation between these two characteristics shows a $\mathrm{rs}=0.199$ and a $p$-value $=$ 0.217 . The same procedure was used for the hypotheses $\mathrm{H} 4 \mathrm{a}$ to $4 \mathrm{c}$.

It is obvious that the classical specialization contents in the business master's program no longer correspond to the requirements of the companies and are therefore subjectively less valuable. This result also leads to the conclusion that advancing digitization is contributing to the fact that decision-making processes that usually require specialized knowledge are increasingly being replaced by algorithms (Ahmad \& Van Looy, 2020).

Comp4a bis 4c. Employers value the methodological competence of MBAgraduates higher than their expertise, social or digital competence

Following, the results of above discussed hypotheses will be summarized in Table 6. The companies mainly see the methodological knowledge at the top, because they need employees who can solve rather difficult situations. At the same time, this is an indication of the great influence of digitization on valueadding processes and its utilization in business decision-making processes.

Comp5: The higher a company's degree of digitalization, the more its representatives are likely to engage in discussions with educational institutions about digitalization

This hypothesis is a correlation hypothesis, the null hypothesis is a digitized company is not very interested in getting involved in education policy issues. In this hypothesis, the nominal-dichotomous variable interest in the exchange of the interval-scaled variable degree of digitization was compared. The first variable is the dependent variable and the latter the independent variable. The ranking correlation analysis was repeatedly used to make a statement. Based on the

Table 6. Hypothesis Comp4a-c.

\begin{tabular}{cc}
\hline rs & $p$ \\
\hline 0.668 & 0.000 \\
0.858 & 0.000 \\
0.854 & 0.000 \\
\hline
\end{tabular}


available data, the single factor variance analysis was calculated with the variable degree of digitization. The correlation between these two characteristics shows a rs $=0.409$ and a $p$-value $=0.009$, thus the hypothesis can be verified.

Comp6: Employers value their employers' modular continuing education (certificate studies, part time studies etc.) higher than compulsory attendance studies

This hypothesis aims to prove a difference between modular continuing education, i.e., certificates, part-time studies, and attendance studies. Consequently, a differential hypothesis was formulated. The associated null hypothesis is: Companies see no difference between modular continuing education and attendance studies. The variables module study, certificates and part-time study were summarized to one single variable named modular continuing education, so that the two normal scaled variables modular continuing education as well as studies with compulsory attendance were compared. As finding it can be derived that the enterprises with the question which qualification measures they strive for in universities starting from the frequencies rather tended to the modular training further possibility than to the operational readiness level study.

Educl: Compared with universities, colleges \& universities of applied sciences prefer modular courses in terms of corporate continuing education instead of compulsory attendance studies

A binomial test will be used to verify or falsify this hypothesis. Here in Table 7, the division of institutions is carried out: colleges and universities. A difference between the modular teaching units and the presence units will be worked out. The null hypothesis is: No difference between universities of applied sciences and universities in the preference for modular continuing education. In a first step, the necessary answers were summarized to a variable "modular continuing education". Subsequently, the binomial test could be performed. The following frequencies could be recorded for universities of applied sciences and universities.

Based on this, the hypothesis can be considered significant. Universities of applied sciences are more agile due to their comparatively higher level of application-oriented knowledge transfer and can therefore adapt to the needs of companies in the short term. In contrast, universities still focus on research and classical teaching.

Educ2: Universities and skills rely on process management for digital competence

Table 7. Hypothesis Educ1.

\begin{tabular}{ccc}
\hline Hypothesis for... & Variables & $p$ \\
\hline $\begin{array}{c}\text { universities of applied } \\
\text { sciences \& colleges }\end{array}$ & Modular studies & 0.000 \\
universities & Modular studies & 0.125 \\
\hline
\end{tabular}


In the context of the expert interviews, the understanding of processes in view of the changes in business studies has emerged as one of the most important digitization modules. Leading nations have been investing in Artificial Intelligence for some years now and have set aside a large budget for it (World Economic Forum, 2020). A PWC survey underlines this statement by concluding that by the third decade of the 21st century, the share of artificial intelligence will increase $14 \%$. The greatest impact tends to be seen in increased customer demand for products and services and a high degree of process automation (PwC, 2020). Artificial intelligence is seen as both, an opportunity as well as a risk. It is perceived as a risk as we do not yet know the full of its potential. In addition to artificial intelligence, cloud computing should also be mentioned, which was also a topic of discussion at the WEF 2020. With the help of cloud computing, more and more data can be stored, and this data is always available regardless of time and location (World Economic Forum, 2020). Based on the existing nominal scale level, the frequencies are considered. Table 8 shows that the process management $\&$ organizations module appears to be numerically more important to universities and colleges (Wieczorek \& Dorčak, 2020).

Digitization is leading to data collection on an unprecedented scale. Both, companies and universities are aware of this situation. In the future, the ability to collect information for a specific purpose and evaluate it in the next step will determine the competitive position. If an unintentional information outflow occurs due to technical deficits, in the worst case, the survival of the company could be threatened.

The efficient evaluation of collected or available information can be considered a competitive advantage. Both, companies and universities have recognized this. Consequently, a revision of the study contents is recognizable throughout Europe (Roblek, Thorpe, Bach, Jerman, \& Meško, 2020).

Group-standards as well as a process-oriented view of the value chain will be the prerequisite for the continued existence of the competitive situation. It is

Table 8. Hypothesis Educ2.

\begin{tabular}{ccc}
\hline Digital modules & University & University of applied sciences \\
\hline Blockchain & 1 & 11 \\
Business Analytics & 4 & 14 \\
Change-Management & 4 & 15 \\
Data Mining & 3 & 9 \\
IT-security & 2 & 14 \\
Artificial intelligence & 2 & 8 \\
Management \& Organization & 5 & 16 \\
Social Media & 3 & 12 \\
Process & 2 & 11 \\
\hline Dealing with mobile computing & & \\
\hline
\end{tabular}


therefore important to emphasize that both, universities and colleges, should recognized the importance of this.

Findings from the hypotheses

Hypotheses Comp1 and Comp2 have shown that large companies have significantly more difficulty adjusting to short-term changes. Consequently, they can only react to trends and market changes to a limited extent. In contrast, small companies can react much more flexibly in these dynamic times, as they do not have the administrative organization and personnel structure.

From the hypotheses Comp3 to 4c it can be deduced that the business management idea is very important today as well as in the future. Companies are still at the cutting edge if they implement standardizable process landscapes and thus enable lean corporate management. User-friendly modular systems are the basis for responding to external changes in an agile manner. In the future, teaching content and interdisciplinary contexts will be available with software support, which will lead to a shift in the compulsory content of business studies. The modules most likely to be affected are human resources, law, purchasing and controlling. It can be assumed that there will be a transformation from manual activities by employees to software solutions. Robotic Process Automation, or RPA for short, and Artificial Intelligence are just two possible representatives at this point that provide support for repetitive, error-prone and time-intensive activities. Despite all this, employees must understand and comprehend the processing by RPA in order to point out errors or, in case of doubt, to be able to take over this work as well. These trends and changes are becoming more and more important in business studies, so universities should see this as an opportunity to rediscover learning content as well as transferable disciplines.

Comp5 has shown that companies with a high degree of digitalization are more interested in becoming involved in higher education, especially in teaching.

The form of business studies should be organized in modules, as shown by the hypotheses Comp6 and Educ1. Classroom teaching will have to adapt and change more and more in the future.

In the digital age the processing of information within seconds is the key to business success (Educ2). For this reason, it is important and purposeful to consider and integrate the modules process management, business analytics, data mining and artificial intelligence in the revision of the curriculum of business administration studies.

\section{Conclusion and Outlook}

The research project examined the changes during the years 2018/2019 (i.e. before the outbreak of the COVID-19 pandemic) caused by digitization, focusing on the current challenges in both, the university and corporate context. We already know by today that the labor market will change (Wieczorek \& Dorčak, 2020). New jobs will be created, but some other jobs will disappear as well (An- 
droniceanu, Georgescu, Tvaronavičiene, \& Androniceanu, 2020). Most of the digital changes affect process management. In essence, it is a matter of interlocking or merging internal processes with external system landscapes. Hence, it is necessary to integrate structured and standardized processes in the company and to collect data in parallel. For this reason, it is no longer pure basic business management knowledge that counts, but rather that companies combine special business expertise and IT understanding in their problem solving. Agility and software-based solutions are playing an increasingly important role in the corporate world. For this reason, IT solutions of this kind should be included in the curricula of business administration-studies. In some business administration modules, such as human resources (personnel recruitment) or controlling (sales planning), a variety of software products based on RPA are already available today to automate repetitive and time-consuming activities and have them solved by algorithms. In this way, tasks are postponed and employees can devote themselves to other activities that cannot be solved by AI. In case of failure, the workforce should know how the processing is done by RPA so that they can intervene if necessary and identify errors.

With digital innovation, unprecedented technologies and innovations are coming our way. In order to keep up with these changes, curiosity and further research are needed to fully exploit these inherent opportunities. Only those who embrace the new technology will be successful in the future (Hajdukiewicz \& Pera, 2020). Universities must incorporate these inevitable changes into curriculum of business administration-studies. Otherwise, future graduates will find it increasingly difficult to integrate into the corporate world.

Since the potential of digitization (including Industry 4.0, artificial intelligence and block chain) is not fully utilized yet, the authors perceive this subject as one of the most eminent research tasks.

The tertiary education sector has also recognized this development and is gradually countering it with new curricula. Another field of research could be the change within teaching through COVID-19. Teaching and also the teaching staff must be able to react more flexible to such deviations. For this purpose, however, the corresponding IT systems and networks have to be provided (Hajdukiewicz \& Pera, 2020). The latter has to be clarified by politics in Germany with reference to the discussions about the expansion of the $5 \mathrm{G}$ network.

In addition, it could be investigated what role will be ascribed to universities in the future in the context of knowledge transfer. Since nowadays more and more information is provided with the help of videos on various platforms, such as YouTube, Instagram or Facebook.

The present research has shown that studies of business administration must change. At this point, the authors summarize the upcoming changes as following: 1) adaptation of business administration curricula with regard to current trends business analytics, blockchain, artificial intelligence, 2) adaptation of IT infrastructure and resources in knowledge transfer such as blogs, online lectures 
and 3) stronger collaboration between business, science and education. The authors had already pointed out essential changes in higher education in 2019. The deficits in higher education became clearer due to the COVID-19 pandemic and a transformation in the higher education sector has to happen right away (Dreyer, 2020). Further, a transformation of teaching and learning is more necessary than ever.

The 2020 summer semester-also known as the "digital semester"-demonstrates that a variety of tools, platforms, and applications have been used to deliver teaching, some of which have been part of the offer in higher education institutions for more than 15 years (Bohnenkamp, 2020). Problems in the context of technical infrastructure and in the transition of face-to-face formats to online formats persist (Dreyer, 2020). Many exploratory studies have addressed digital changes in teaching and learning in higher education since 2020. Further studies will deal with the technical infrastructure, communication and exchange between teachers and learners as well as didactics.

\section{Conflicts of Interest}

The authors declare no conflicts of interest regarding the publication of this paper.

\section{References}

Ahmad, T., \& Van Looy, A. (2020). Business Process Management and Digital Innovations: A Systematic Literature Review. Sustainability, 12, 6827. https://doi.org/10.3390/su12176827

Androniceanu, A., Georgescu, I., Tvaronavičienè, M., \& Androniceanu, A. (2020). Canonical Correlation Analysis and a New Composite Index on Digitalization and Labor Force in the Context of the Industrial Revolution 4.0. Sustainability, 12, 6812. https://doi.org/10.3390/su12176812

Bauer, U., \& Sadei, C. (2015). Studie zur Employability der TU Graz Absolvent/inn/en2015: Ergebnisse einer Primärerhebung unter Arbeitgeber/inne/n und TU Graz Absolvent/inn/en. https://www.econstor.eu/bitstream/10419/147510/1/865219753.pdf

Bohnenkamp, B. (2020). Online-Lehre 2020-Eine medienwissenschaftliche Perspektive. https://hochschulforumdigitalisierung.de/sites/default/files/dateien/HFD DP 10 Onli ne-Lehre 2020 Eine medienwissenschaftliche Perspektive.pdf

Bundesministerium für Bildung und Forschung (2020). Bekanntmachung der ZusatzVerwaltungsvereinbarung “Administration” zum DigitalPakt Schule 2019 bis 2024. https://www.bmbf.de/foerderungen/bekanntmachung-3271.html

Casper-Hehne, H., \& Reiffenrath, T. (2017). Hochschulbildung in globalen und lokalen Kontexten: Das Göttinger Modell einer Internationalisierung der Curricula. https://www.ssoar.info/ssoar/bitstream/handle/document/55106/ssoar-interculturej-20 17-27/28-casper-hehne et al-Hochschulbildung in globalen und lokalen.pdf?sequen $\mathrm{ce}=1$

Dreyer, M. (2020). IT, Medien und digitale Lehre-Infrastruktureinrichtungen im Digitalsemester. https://hochschulforumdigitalisierung.de/de/blog/digitale-lehre-umfrage

Hajdukiewicz, A., \& Pera, B. (2020). Education for Sustainable Development-The Case of Massive Open Online Courses. Sustainability, 12, 8542. 
https://doi.org/10.3390/su12208542

Hessler, G. (2013). Employability in der Hochschule? Analysen zur Perspektive von Studierenden der Sozial-und Geisteswissenschaften. Bielefeld: Universität Bielefeld. https://doi.org/10.3217/zfhe-8-01/06

Hirsch-Kreinsen, H. (2017). Arbeiten 4.0-Qualifikationsentwicklung und Gestaltungsoptionen. Hamburg 2017.

Kirsch, W., \& Picot, A. (2013). Die Betriebswirtschaftslehre im Spannungsfeld zwischen Generalisierung und Spezialisierung. Gabler Verlag: Wiesbaden.

Kröber, E. (2017). Grundsätze hochschuldidaktischer Arbeit: Am Zentrum für Lehre und Weiterbildung. https://elib.uni-stuttgart.de/handle/11682/9227

PwC (2020). Sizing the Prize. What's the Real Value of AI for Your Business and How Can You Capitalise?

https://www.pwc.com/gx/en/issues/analytics/assets/pwc-ai-analysis-sizing-the-prize-re port.pdf

Roblek, V., Thorpe, O., Bach, M. P., Jerman, A., \& Meško, M. (2020). The Fourth Industrial Revolution and the Sustainability Practices: A Comparative Automated Content Analysis Approach of Theory and Practice. Sustainability, 12, 8497.

https://doi.org/10.3390/su12208497

Wieczorek, S., \& Dorčak, P. (2020). Auswirkungen von Industrie 4.0 auf das Studium der Betriebswirtschaft-Eine Analyse des Status Quo (pp. 17-18). Frankfurt am Main: Neowiss-Europäischer Wissenschaftsverlag.

World Economic Forum, WEF (2020). Technology Can Be a Great Ally in the Drive for Greater Inclusion and Diversity. https://www.weforum.org 